\title{
Students' Perception Towards Engaging Factors of Extreme e-Service Learning Design for Computer Network Course
}

\author{
https://doi.org/10.3991/ijim.v15i05.20901 \\ Valerie Bukas Marcus ${ }^{(凶)}$, Noor Azean Atan, Sanitah Mohd Yusof, \\ Umi Mastura \\ Universiti Teknologi Malaysia, Skudai, Malaysia \\ valeriebukas92@gmail.com
}

\begin{abstract}
Impact brought by COVID-19 changes the whole classroom culture from face to face to the extreme online learning and this includes a course that normally implements traditional face-to-face Service Learning. Educators are required to shift the learning into the online platform which is also known as Extreme e-Service Learning and it must be prepared in a proper way. In keeping students engaged with their learning, Extreme e-Service Learning needs to be designed based on engaging factors to encourage and support student engagement with their learning. Thus, in this study, researcher designed the Extreme e-Service Learning online platform based on the engaging factors and at the same time, investigating students' perceptions towards this learning design. A set of questionnaires were distributed and analysed. Semi-structured interviews with students in a smaller group were conducted to have a deeper insight. Research findings suggest that students have positive views and perceptions in regard of using Extreme e-Service Learning mainly because of the learning activities and interesting features in this online platform. This study contributed to the design of Extreme e-Service Learning based on engaging factors that help e-Service Learning instructors in planning their teaching and learning process and ensure engaging experience for the students.
\end{abstract}

Keywords-e-Service Learning, Online Service Learning, Student Engagement, Extreme E-Service Learning

\section{Introduction}

The COVID-19 pandemic has caused the largest disruption of education systems in history. With the increased concern about the spread of COVID-19, university campuses are required to close down during the quarantine time since March 2020. In this uncertain time, some academic courses transition to online instruction, but most of the co-curricular, extra-curricular activities, and student affairs' events which highly depend on face-to-face interactions are cancelled or postponed. Service Learning is not an exception. During the past few months, a great number of Service-Learning programs in higher education has been cancelled and suspended. 
The closing of educational institutions due to the pandemic has transform the way Service Learning was conducted. While facing the guideline of social distancing, conducting on-site Service Learning is not feasible and educators are opt to conduct virtual Service Learning which is also known as e-Service Learning. Waldner, et al. [1] defined e-Service Learning as the instructional component, the service component, or both are conducted online. They assert that e-Service Learning generally occurs in a hybrid model, with some aspect of instruction and / or service occurring online. Thus, there is a growing body of research investigating the design and development of e-Service Learning to guide educators in this new area. In fact, it was the most researched topic in e-Service Learning area for the past few years [2].

Transitioning traditional Service Learning into online platform is not an easy task. In traditional setting of Service Learning, students are able to interact face to face and collaborate by doing physical activity together. Interaction between students and teacher are more visible. In contrast, conducting Service Learning in online platform can make students feel disconnected to the community, classmates and instructor due to the irregular synchronous communication. Some may suggest that service learning cannot work in a fully online format because there is no physical face-to-face interaction with the community partner [3]. Therefore, it is difficult to foster an environment of "teamwork" and collaboration, which is a very crucial element to a productive service-learning experience. Instructors must plan accordingly and structure course components that build rapport with students and between teams and the community by using live video sessions, breakout groups in the course shell, or group project work [3]. To overcome student disconnection, instructors are encouraged to allow opportunities for reflection among students. Thus, it is necessary to design the e-Service Learning based on engaging factors to encourage and support student engagement with their learning.

In this study, researcher designed the Extreme e-Service Learning online platform based on the engaging factors and at the same time, investigating students' perceptions towards this learning design. This way, it can help instructors of e-Service Learning to understand the student engagement better, help students reflect on their learning behavior and promote their deep participation in the learning process [4]. Only by actively engage then students can be benefitted from the online e-Service Learning.

\section{$2 \quad$ Literature Review}

\subsection{E-service learning}

E-Service Learning occurs when either instructional or service component or both are conducted online [1].They revealed that there are four types of e-service-learning: Hybrid Type I involves course instruction delivered online with the service-learning component being completed onsite at a community site. Hybrid Type II involves course instruction being delivered onsite in a face-to-face manner with the service-learning component being completed entirely online. Hybrid Type III involves a hybrid approach where both instruction and service are taught onsite and online. Type IV, otherwise known as extreme e-Service Learning consists of instruction and service-learning experience being completed entirely online. 
Each type of e-Service Learning may lead to different products and outcomes. For example, Hybrid Type II (service fully online with teaching fully on site) appears to be restricted to one specific discipline which is information technology courses due to the nature of service that can be conducted online. Meanwhile, Hybrid Type I and Type III often required participants to travel for service. Extreme e-Service Learning usually limits students with limited product such as writing grant or policy analysis for the community partner [5]. The civic engagement between students and community partner appear to be lesser in extreme e-Service Learning compared to the other type of e-Service Learning due to everything is online. The stages of conducting Service Learning will be the same be it in traditional face-to-face Service Learning or e-Service Learning. Kaye [6] stated that stages of Service Learning must consist of five phases which are (i) inventory and investigation, (ii) preparation and planning, (iii) action, (iv) reflection and (v) demonstration.

According to Waldner, et al. [3], there are five issues happened in extreme e-Service Learning course. Firstly, the issue of lurking where students log into the session but fail to participate. Secondly, there were unbalanced participation where students type text in live session instead of participating verbally. Thirdly, there were also issue related to technology where each individual skills level of using technology were different from each other, software and hardware limitations, firewall and other unpredicted problems involving technology. Next, the timeframe of the course that is too compress may hinder full product development and jeopardize the quality of the product. Last but not least, student often disconnect in this Type IV setting due to lack of student-to-student interaction, student to client and/or student to instructor. In recent study by Bharath [7], he identified that time commitment was the greatest challenge while implementing extreme e-Service Learning, fewer active participants came second, and another challenges such as undervalued the Service Learning opportunities and therefore, caused the students to have lack of interest in Service Learning.

Implementation of e-Service Learning is challenging but there has been a growing body of research investigated the best practice for e-Service Learning. Salam, et al. [8] proposed a technological framework for e-Service Learning and suggest that educators should integrate suitable technology for each phases of e-Service Learning depending on their objectives and the nature of the projects too. In transforming to extreme eService Learning, flexibility is very crucial for educators and students [9]. Flexibility enables instructors to think creatively and work through unforeseen situation, meanwhile students can benefit from this as this is the opportunity to nurture resourcefulness and creative thinking skills among them. Major concern for students' disconnection can be overcome with learning activities that require teamwork among students, live with client sessions and having breakout discussions, choose client that is willing to work with technology, allow opportunities for reflection and archive synchronous events for later student viewing [3].Apart from this, Bharath [7] assert that thorough planning and constant communication is one of the key for successful e-Service Learning. It is essential for instructors to regularly communicate with students and community partners through whatever communication medium that are available to ensure to that projects were moving forward. Communication is crucial to make certain all participants were doing their roles.

In a nutshell, Service Learning or e-Service Learning component should follow some common best practices and design principles to ensure the success of the project by 
following the three Rs of Service Learning courses - reality, reciprocity and reflection [10]. Reality refers to fulfil a genuine community need; reciprocity ensure that the project provide benefits to both the students and the community partner and reflection allows students to directly connect the service performed to the course learning objectives. With this in mind, educators can be confident that the class structure and design is suitable for e-Service Learning.

\subsection{Student engagement and engaging factors}

Student engagement in classroom activities is essential to student's success in the learning process. Depending on the context, different definitions in the literature were established to highlight the various relevant attributes of engagement. Fredricks [11] define student engagement as meta-construct consists of behavioural, emotional and cognitive engagement. According to Fredricks [11], Axelson and Flick [12] assert student engagement as the involvement, interest and connectedness that learners have with their courses, their classmates and their institution of instruction. Meanwhile, Schlechty [13] defined student engagement as the level of attention and commitment students have in a lesson. He also presented that there are five distinct categories of student engagement in learning tasks and activities which is engagement, strategic compliance, ritual compliance, retreatism and rebellion. Knowing how student engaged in a learning process is crucial so that instructor of the course will be able to improve the design of the course in the future.

Stroud [14] proposed student engagement theory with the use of technology based on the combination of four of the most prominent theory in student engagement research; Achievement Goal Theory (AGT), Self-Determination Theory (SDT), Expectancy-Value Theory (AVT) and Social Cognitive Theory (SCT). The combination of these theories creates a clear picture of necessary component of learning to help promoting student engagement especially in involving technology. The theory stated that learners will become most engaged when these elements are present in the learning process while integrating technology; clarifying expected performance, setting goals in the learning, providing feedback on performance, rewarding effort, performance and outcome and lastly, tracking changes in performance across time.

Clarify expected performance: Learners need to understand what is considered as 'good' performance before they can direct their actions to try to perform well on their own. Technology such as video tutorials, screen casting tools and demonstration tools are proven to motivate and engage learners significantly during their learning by clarifying their expected performance. These tools can be used to pinpoint the strong and weak areas of previous performance of the same work and provide learners a clear insight of expectations from the start.

Setting goals in learning: Learners need to be engaged on specific goals and personal growth during their learning. Technology that has self-regulated electronic diaries to set and monitor goals and performance within task is proven to makes learners become more engaged over time.

Providing feedback on performance: Learners that understand how they are performing resulting to better understanding of their abilities and performance thus stir up more motivation for their upcoming attempts. Video recordings with self-reflection of performance, student response system are few examples of technological tools that can 
boost learners' confidence simultaneously making them more positive and focus in improving which is crucial for engagement.

Rewarding effort, performance and outcome: Learners that received response for their work impact their attitude and effort in upcoming attempts. It is crucial to ensure that learners receive positive and encouraging rewards for the work they do. Electronic leaderboards and game scoring systems has been found to improve student engagement significantly. The integration of such tools into the learning is able to create more engaged classrooms and supporting student engagement.

Tracking changes in performance across time: Learners that able to see their progress over time is expected to become more motivated and engaged in the future. Technology such as electronic diaries created using table in Excel sheet is able to help learners visualize different aspects of their performance within discussion from class to class and they will try to improve in the areas that they weak in each new attempt. The key for engagement is the ability to see personal growth.

While it is good to ensure that all five elements are present, Stroud mentioned that it is not necessary as long as it fits the nature of the course. Also, Stroud advised that instructors can always their own observations and self-reported data from students to assess the engaging factors and further tune the use of technology in order to support student engagement. It is also important to note that Bond and Bedenlier [15] highlighted that integration of technology in education can facilitate engagement only if students find it meaningful, related to real life and can act without anxiety. Therefore, it is not just technology equals to student engagement but it is also depending on the overall of the learning environment too.

\subsection{Authentic learning environment}

Authentic learning environment was originated from Situated Based Learning [16]. Authentic learning typically focuses on real-world, complex problems and their solutions and learning environments are inherently multidisciplinary (Herrington \& Oliver, 2000). In short, authentic learning environment is a learning environment that is similar to some 'real world' situation. Students that immersed in authentic learning activities nurture the kinds of "portable skills" that will benefit them in the future. One common thing that similar among Service Learning and Authentic Learning is that it required students to reflect upon their learning apart from selecting project that is as real as possible. Herrington, et al. [17] suggests that the use of authentic learning setting can provide strong supports for learners in online environment as student immersed in the setting and such immersion can provide the motivation that is needed to persevere throughout the learning process. This is actually in line with the student engagement definition that is defined by Schlechty [13] as the level of perseverance in learning process. By designing Service Learning in Authentic Learning environment, researcher believe that this can support and enhance student engagement. There are nine characteristic of Authentic Learning according to Herrington and Oliver [18] as listed below:

1. Authentic Learning provide an authentic context that reflects the way the knowledge will be used in real life.

2. Authentic Learning provide authentic task.

3. Authentic Learning provide access to expert performances and modelling of process. 
4. Authentic Learning provide multiple roles and perspectives during teaching and learning process.

5. Authentic Learning can support collaboration of knowledge construction among the learners.

6. Authentic Learning promote reflection to enable abstraction to be formed.

7. Authentic Learning promote articulation of idea in order to enable tacit knowledge to be made explicit.

8. Authentic Learning provide coaching and scaffolding.

9. Authentic Learning provide authentic assessment of learning within the tasks.

In this study, researchers are implementing suitable elements of Authentic Learning in every phase of e-Service Learning to provide the authentic learning experience for students.

\subsection{Conceptual frameworks for designing extreme e-service learning}

Based on the literature above, this study proposed a combination of engaging factors and authentic learning design for Extreme e-Service Learning to optimize the learning experience among students as shown in Fig 1.

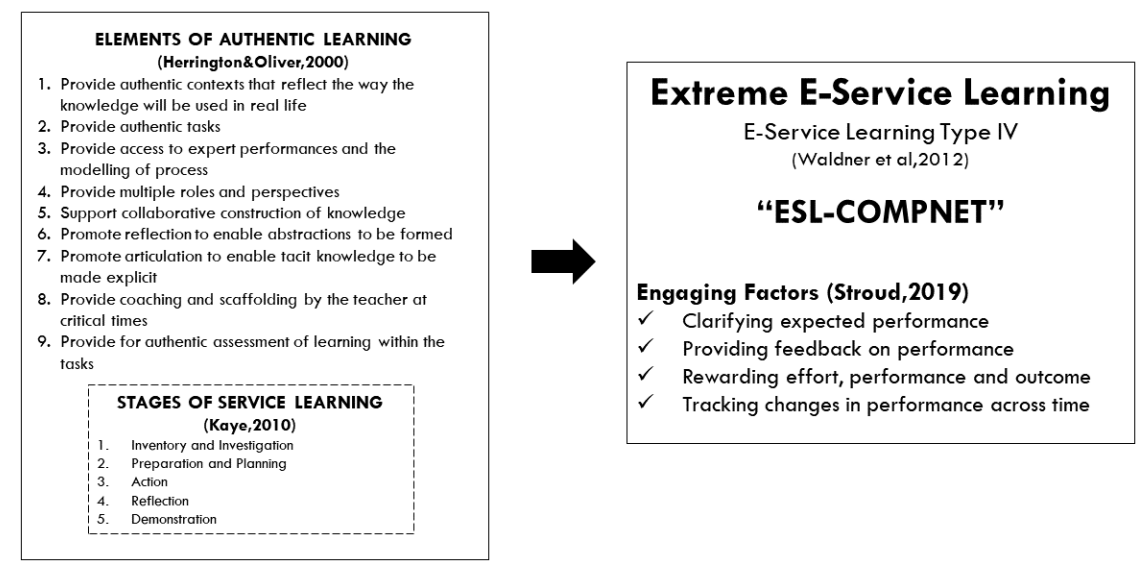

Fig. 1. Conceptual Framework for Extreme e-Service Learning Design

In this study, researchers injected relevant elements of Authentic Learning in every stages of e-Service Learning to create Authentic Learning environment. For example, during the first stages of inventory and investigation, instructor is bound to provide coaching and scaffolding to assist the students in doing their preliminary research about the community. All of these elements are happening in the online platform provided which researchers called as ESL-COMPNET. In this online platform, there are four engaging factors identified as available in it to enhance student engagement throughout the e-Service Learning which are (i) clarifying expected performance, (ii) providing feedback on performance, (iii) rewarding effort, performance and outcome and (iv) tracking changes in performance across time. Online platform will be used to provide the authentic learning activities and giving support of reflection and engagement 
through technological tools. In this study, researcher decide to seek upon one online platform that can be use through web-based application and mobile application for easy access that can fit as many as engaging factors listed by Stroud [14]. This is because using too many technological tools can be a burden to students especially in e-Service Learning. Thus, after the thorough comparison of learning application existed out there, researcher decided to use ClassDojo. ClassDojo is well known as digital token economy mobile application because of the interactive distribution of points for targeted behaviours given to the students [19]. However, little did educators known that ClassDojo also provided very attractive learning functionality where students can share their works and learning activities in the class through various forms of media such as written text journal, photo, video and drawing. Researchers of this study sees this function is very useful for assisting the reflection process as reflection is a continuous process in eService Learning. In fact, reflection is what distinguishes Service Learning from volunteerism and makes it more than community service [20].

To summarize the discussion so far, researchers would like to propose Extreme eService Learning design based on authentic learning environment where the online platform must have the engaging features that will helps to enhance student engagement throughout the e-Service Learning. Therefore, in this study, after from designing the learning activities in e-Service Learning, it is also important to receive feedback and gain deeper insight from the participants of this study regarding the design of the online platform.

\section{Methodology}

\subsection{Research design}

This research was conducted on the basic of the case study model. According to Yin [21], a case study is appropriate for research that want to gain concrete, contextual and in-depth knowledge about specific real-world subject. Researcher also want to explore a single subject study to improve the quality of Extreme e-Service Learning program especially in the online platform.

\section{2 $\quad$ Setting}

This case study was set in one the local universities in Malaysia. It involved 22 undergraduates' students who participated in one of the e-Service Learning courses. All these students came from across discipline that participated together to conduct e-service learning project based on computer networking course. The project involved students teaching basic of computer network and cabling installation to the community, 33 secondary school students aged 16-year-old through Google Classroom and Google Meet for one month.

An online platform, ClassDojo was setup in authentic learning setting according to the conceptual framework that has been discussed before. Instructors shared teaching materials and learning activities in the online platform and able to give feedback to the student through comment section. Meanwhile, students used the online platform mainly 
for their reflection activity throughout the e-Service Learning course. This research was conducted for one whole semester from February to June 2020.

\subsection{Instruments}

This study is using an online platform and questionnaire as research instruments to achieve the purpose of the study. An online platform has been set up for the purpose of the research. A set of questionnaires consists of 16 statements regarding students' perceptions towards the engaging factors in the online platform. The 16 statements in the questionnaire is adopted and adapted from Cetin and Cetin [22] and Stroud [14]. It consists of 5 Point of Likert Scale where student need to indicate their level of agreement with each statement by selecting appropriate choice whether they are 'Strongly Disagree $=1$, Disagree $=2$, Neither Agree nor Disagree=3, Agree=4 and Strongly Agree $=5^{\prime}$ as shown in Table 1 .

Table 1. Statements in the Questionnaire

\begin{tabular}{|c|c|c|c|c|c|c|}
\hline No. & Statement & $\begin{array}{l}\text { Strongly } \\
\text { Disagree }\end{array}$ & Disagree & $\begin{array}{c}\text { Neither Agree } \\
\text { nor Disagree }\end{array}$ & Agree & \begin{tabular}{|c|c|} 
Strongly \\
Agree
\end{tabular} \\
\hline 1 & This online platform attracted my attention. & & & & & \\
\hline 2 & $\begin{array}{l}\text { This online platform makes me put more ef- } \\
\text { fort in the course since we started using it. }\end{array}$ & & & & & \\
\hline 3 & $\begin{array}{l}\text { This online platform increased my attention } \\
\text { since I started using it. }\end{array}$ & & & & & \\
\hline 4 & $\begin{array}{l}\text { This online platform increased my self-con- } \\
\text { fidence. }\end{array}$ & & & & & \\
\hline 5 & $\begin{array}{l}\text { This online platform bothered me with the } \\
\text { competitive feeling of competition. }\end{array}$ & & & & & \\
\hline 6 & $\begin{array}{l}\text { This online platform enables good sharing } \\
\text { of class activities by my teacher. }\end{array}$ & & & & & \\
\hline 7 & $\begin{array}{l}\text { This online platform increased my motiva- } \\
\text { tion in the class. }\end{array}$ & & & & & \\
\hline 8 & $\begin{array}{l}\text { This online platform would be good to use } \\
\text { in other courses too. }\end{array}$ & & & & & \\
\hline 9 & I can follow myself in this online platform. & & & & & \\
\hline 10 & $\begin{array}{l}\text { I try to show positive behavior in this online } \\
\text { platform. }\end{array}$ & & & & & \\
\hline 11 & I am interested in this online platform. & & & & & \\
\hline 12 & $\begin{array}{l}\text { This online perform show me the expected } \\
\text { performance that I need to do well in this } \\
\text { course. }\end{array}$ & & & & & \\
\hline 13 & $\begin{array}{l}\text { This online platform helps me to set goals } \\
\text { in the learning. }\end{array}$ & & & & & \\
\hline 14 & $\begin{array}{l}\text { This online platform providing feedback on } \\
\text { my performance. }\end{array}$ & & & & & \\
\hline 15 & $\begin{array}{l}\text { This online platform shows the rewarding } \\
\text { effort, performance and outcome. }\end{array}$ & & & & & \\
\hline 16 & $\begin{array}{l}\text { This online platform helps me to track } \\
\text { changes in my performance across time. }\end{array}$ & & & & & \\
\hline
\end{tabular}


According to Santos [23], reliability is very important when variables developed as predictor of objective of the study. Reliability is synonymous with the consistency of a test, survey, observation or other measuring device. Cronbach's alpha tests is to see if multiple question Likert scale surveys are reliable. These questions measure latent variables - hidden or unobservable variables like a person's conscientiousness, neurosis or openness. As these are very difficult to measure in real life, Cronbach's alpha will tell the researcher if the survey they designed is accurately measuring the variable of interest. Analysis of the instrument showed high level of consistency which is Cronbach's $\alpha$ of 0.88 as shown in Table 2. As stated by George and Mallery [24], the closer the coefficient is to 1.0, the greater is the internal consistency of the items in the scale. Therefore, this instrument is suitable to be used.

Table 2. Cronbach's ó for Questionnaire Items

\begin{tabular}{|c|c|c|}
\hline Cronbach's Alpha & Cronbach's Alpha Based on Standardized Items & N of Items \\
\hline .882 & .888 & 16 \\
\hline
\end{tabular}

For the semi structured interviews, researcher is asking four questions regarding the online platform after the introduction session as shown in Table 3. These questions were prepared to gain deeper insight of how students feel regarding their engagement through the online platform.

Table 3. Semi Structure Interview Questions

\begin{tabular}{|l|l|}
\hline \multicolumn{1}{|c|}{ Category of Questions } & \multicolumn{1}{c|}{ Questions } \\
\hline Introduction Questions & 'Introduce yourself' \\
\hline \multirow{3}{*}{$\begin{array}{l}\text { Questions regarding Online } \\
\text { Platform }\end{array}$} & $\begin{array}{l}\text { 1. What was the best thing about using this online platform? } \\
\text { 2. What was the worst thing about using this online platform? } \\
\text { 3. How can we improve the use of the online platform during this course? } \\
\text { 4. How does this online platform help in your e-Service Learning activity? }\end{array}$ \\
\hline
\end{tabular}

\subsection{Procedure and data collection}

Researcher has planned and carried out the pilot study that involved a total of 22 undergraduates' students in one of the Service Learning courses in first semester of 2019/2020. With this application, students were able to follow themselves, get instant feedback from lecturer and evaluate themselves. At the end of the course, questionnaire is distributed and students were required to respond in one day. Researcher also collect the data through semi-structured interview as respondents were allowed to include more information, including feelings, attitudes and understanding of the subject. This enable researchers to better access the respondents ' true feelings on an issue [25].Ten students were selected for the semi-structured interview. Interview session was conducted for about two hours. 


\subsection{Data analysis}

Analysis of the questionnaire is presented based on descriptive statistic. Likert scale data are analysed at the interval measurement scale. Likert scale items are created by calculating a composite score (sum or mean) from four or more type Likert-type items; therefore, the composite score for Likert scales should be analysed at the interval measurement scale [26]. Descriptive statistics recommended for interval scale items include the mean for central tendency and standard deviations for variability. Meanwhile, interviews from the student were transcribed in NVIVO and researcher analyse their answers by using thematic analysis to identify common themes or pattern of meaning that come up repeatedly.

\section{$4 \quad$ Results and Findings}

This section includes the findings and comments that fit the purpose of the study which is to investigate students' perceptions towards engaging factors of this learning design. A general evaluation of students' opinions on the online platform was made using descriptive statistics and the result are presented in Table 1. The descriptive statistical results obtained distributed to the participants are given in Table 1. Apart from that, researcher also conducted semi-structured interview to have deeper insight about students' perception towards the engaging factor in the online platform. Table 1 show the analysis of students' perception towards engaging factors in the online platform.

Table 4. Analysis of Students' Perception towards Engaging Factors

\begin{tabular}{|c|l|c|c|c|c|c|c|c|}
\hline No. & \multicolumn{1}{|c|}{ Statement } & $\begin{array}{c}\text { Strongly } \\
\text { Disagree }\end{array}$ & $\begin{array}{c}\text { Dis } \\
\text { agree }\end{array}$ & $\begin{array}{c}\text { Neither } \\
\text { Agree nor } \\
\text { Disagree }\end{array}$ & Agree & $\begin{array}{c}\text { Strongly } \\
\text { Agree }\end{array}$ & Mean & S. D \\
\hline 1 & This online platform attracted my attention. & 0 & 0 & 3 & 10 & 9 & 4.27 & 0.703 \\
\hline 2 & $\begin{array}{l}\text { This online platform makes me put more ef- } \\
\text { fort in the course since we started using it. }\end{array}$ & 0 & 0 & 4 & 10 & 7 & 4.05 & 0.844 \\
\hline 3 & $\begin{array}{l}\text { This online platform increased my attention } \\
\text { since I started using it. }\end{array}$ & 0 & 0 & 6 & 9 & 7 & 4.05 & 0.785 \\
\hline 4 & $\begin{array}{l}\text { This online platform increased my self-con- } \\
\text { fidence. }\end{array}$ & 0 & 1 & 6 & 9 & 6 & 3.91 & 0.868 \\
\hline 5 & $\begin{array}{l}\text { This online platform bothered me with the } \\
\text { competitive feeling of competition. }\end{array}$ & 3 & 3 & 7 & 5 & 4 & 3.18 & 1.296 \\
\hline 6 & $\begin{array}{l}\text { This online platform enables good sharing } \\
\text { of class activities by my teacher. }\end{array}$ & 0 & 0 & 2 & 8 & 12 & 4.45 & 0.671 \\
\hline 7 & $\begin{array}{l}\text { This online platform increased my motiva- } \\
\text { tion in the class. }\end{array}$ & 0 & 0 & 5 & 12 & 5 & 4.00 & 0.690 \\
\hline 8 & $\begin{array}{l}\text { This online platform would be good to use } \\
\text { in other courses too. }\end{array}$ & 0 & 0 & 3 & 8 & 11 & 4.36 & 0.727 \\
\hline 9 & I can follow myself in this online platform. & 0 & 0 & 2 & 11 & 9 & 4.32 & 0.646 \\
\hline 10 & $\begin{array}{l}\text { I try to show positive behaviour in this } \\
\text { online platform. }\end{array}$ & 0 & 0 & 4 & 8 & 10 & 4.27 & 0.767 \\
\hline 11 & I am interested in this online platform. & 0 & 0 & 4 & 8 & 10 & 4.4 & 0.767 \\
\hline
\end{tabular}




\begin{tabular}{|l|l|c|c|c|c|c|c|c|}
\hline 12 & $\begin{array}{l}\text { This online perform show me the expected } \\
\text { performance that I need to do well in this } \\
\text { course. }\end{array}$ & 0 & 1 & 2 & 15 & 4 & 4.00 & 0.690 \\
\hline 13 & $\begin{array}{l}\text { This online platform helps me to set goals } \\
\text { in the learning. }\end{array}$ & 0 & 2 & 3 & 12 & 5 & 3.91 & 0.868 \\
\hline 14 & $\begin{array}{l}\text { This online platform providing feedback on } \\
\text { my performance. }\end{array}$ & 0 & 0 & 3 & 12 & 7 & 4.18 & 0.664 \\
\hline 15 & $\begin{array}{l}\text { This online platform shows the rewarding } \\
\text { effort, performance and outcome. }\end{array}$ & 0 & 1 & 6 & 11 & 4 & 3.82 & 0.795 \\
\hline 16 & $\begin{array}{l}\text { This online platform helps me to track } \\
\text { changes in my performance across time. }\end{array}$ & 0 & 0 & 7 & 10 & 5 & 3.91 & 0.750 \\
\hline \multicolumn{7}{|l|}{ Total Mean } \\
\hline
\end{tabular}

Based on the Table 1, it is seen that students engaged positively in a broad sense. Firstly, students express more positive opinions about good sharing of class activities by their teacher $(\mathrm{N}=22$, Mean=4.45). Next, students express their interest in this online platform $(n=22$, Mean=4.4). Students also express their positive opinion about using this online platform for other courses too $(\mathrm{N}=22$, Mean=4.36). Apart from that, students believe that they can follow themselves in this online platform $\mathrm{N}=22$, Mean $=4.32$ ). They also express that they try to show positive behaviour in this online platform and undeniably this online platform attracted their attention $(\mathrm{N}=22$, Mean $=4.27)$. Last but not least, students opined positive opinion about this online platform that provide feedback on their performance $(\mathrm{N}=22$, Mean=4.18). On interesting note, students have mix opinion regarding their competitive feeling of competition in this online platform. Conclusively, students have various positive view regarding the engaging factors in this online platform with total mean of 4.04 .

The results presented above can be summarized in three main points. First, students agreed that good sharing of class activities by their teacher affect their engagement the most when using the online platform. Undeniably, teaching and learning activities that were provided in the online platform is crucial in determining student engagement. Alongside with teachers' role that activate the students in the class through activities such as group discussion, Almarghani and Mijatovic [27] believed that it can help influence student engagement. Jaggars, et al. [28] also emphasized that when teachers in online environment plays active role, it can enhance student academic performance and retention for a long period of time. Cole [29] also found out that interactive learning activities not necessarily the technology is the one that promote the student engagement with their lesson. This is also supported by participants in the interview when they acknowledge that teaching and learning activities provided through the online platform help them to engage with learning particularly the reflection activity. Abas [30] stated that when students involved in the learning as they ponder upon reflection questions, student engagement can be achieved. Specifically, engagement at cognitive level will be achieved when students are given academically challenging tasks and interactions as well as provided with opportunities to partake in authentic and experiential learning.

As one student shared during the semi-structured interview, "Things that pique my interest it that I can relate to my daily lives make it easier to remember. The hands-on 
activities and online quizzes were fun." Another interesting point made by one of the students goes like this:

"I think it depends on the students ' interests and awareness on the work/course/subject. Regardless of the teacher's efforts, if the student has no interest in the subject, it would be hard to avoid the tendency of students to study only for the test. However, the overall learning experience might provide a new perspective to students to understand what they are studying and the importance of it. This could be done by stressing on the relevance of the subject and how it applies to the students 'personal or professional lives later on. I believe I have always had a more engaging and fulfilled experience when I am assured that the activities or things that I do and learn in the subject actually benefits me. This is naturally done when the teacher puts effort into the lesson preparations and pays attention to details. These small things somehow collectively convince me that the lesson is important and gets me to pay attention and put more effort into the work/course/subject."

This is also in line with what Bond and Bedenlier [15] stated that the integration of educational technology facilitates engagement if students find it meaningful, related to real life and can act without anxiety. This finding also agrees with Bergdahl, et al. [31] that when teachers arranged technologies to enable a variety of interactions to influence learning, engage all students and request insight into student learning processes, though it is rare pedagogically but it can be successful in engaging students when implemented. Teaching practices need to ensure that learning activities offer the possibility for all students to engage as high level of engagement correlate with learning activities provided [31].

Second, students admit that they become engaged with their learning because of the attractive features of the online platform. Many students commented in the interviews that this online platform is very easy to access anywhere and anytime they want because of its mobility. One of the students said, "This apps is very effective and easy to access. This apps can be downloaded from stores and also can save as much time. Unlike the learning management system provided by the university, we are required to open the browse and login." The online platform is very simple, straightforward and easy to use.

One of the students commented said, "I can easily write down my reflection and send to my lecturer rather than pen and paper." Another student adds, "The features in this online platform makes the process of writing and summarizing reflection is easier."

"The best thing, we can make the post our story photo/journal/draw in how our learning day through the online platform. As that our friend and our teacher can see what our progress in our learning process in the online platform," said one student. Apart from this, one of the students commented, "It is fun and easy way to upload your progress and was similar to social media making it fun and interactive."

The ability of online platform that can provide feedback interestingly with point excites student and motivate them to show more positive behaviour in online classroom. Just like what has been highlighted by Bharath [7], the most challenging part in implementing e-Service Learning is time commitment and with this application, it actually saves a lot of students' time because of the simple and straightforward features. Time was a common barrier to reflection [32] as students need to think and gather their 
thought then putting in into words that can express their thinking. Another interesting answers from student goes like:

"I was able to gather my thoughts and do reflections on my recent activities on the course and understand the purpose of activities. I might not have allocated time myself to do it if it were not for this online platform. Hence, the quality of class is better as we are encouraged to take time and review the things we have learnt during that lesson." This finding suggest that the mobility of the app eases their reflection process which is very crucial in engaging them. This findings also conform with Cole [29] where student appear to be more engaging when the social technologies that they used were perceived to be fun.

Third, students engaged more when they feel safe in the learning environment especially in online learning environment. This is because online learning environment have mitigating factor which is isolation that can be against the successful engagement with the course. Cohen [33] stated that technology lacks human component thus can lead to feelings of isolation among learners. Therefore, it is crucial to create the sense of belonging in an online course. One student expressed in the interview, "This online platform enables me to freely give feedback on the course without feeling shy to open up." The online platform also "get us to express our feelings after each activity carried out," said one of the students. Another student said that "This platform provides a private place in freely open up and help us to be honest with our own opinion about the course." A student also commented that "I can easily express my feelings after finishing the class." This finding once again conform the statement from Bond and Bedenlier [15] saying that student engagement can be facilitated when students can act without anxiety during the learning process. It is proven that the learning environment provided in this study creates a safe space for the student to share their feeling, simultaneously engaged them with their learning.

Interestingly, among all the engaging factors as suggested by Stroud [14] , 'providing feedback on my performance' have higher positive opinion from the students. This suggest that students valued instructors' effort in giving feedback such as through comment or personally coaching them via text messaging application. Researchers believe this effort helps student to monitor their performance throughout the e-Service Learning. According to Darling-Hammond [34], feedback is important for professional development. Providing feedback to students improve their ability to reflect thus resulting in more engagement with learning process [35].

However, the main downside of using online platform for the Extreme e-Service Learning are the need of internet availability to access the online platform and some student faced account login issues. It is inevitable situation that while conducting eService Learning, there are many kinds of unexpected technical problem involving technology that are bound to happen. This has been highlighted by Schindler, et al. [36] that instructors should be mindful of privacy, security and accessibility issues when using technologies in learning. Instructor of the e-Service Learning course is advised to be equip with knowledge to troubleshoot the online platform. During this crisis, a great deal of flexibility are required from both learners and educators [37]. Through this process, it encourages resourcefulness and creative thinking skills both from instructors and students to overcome this challenge. 


\section{Conclusion}

Educators have to shift the landscape of teaching and learning in classroom into online distance learning in order to prevent the spread of the virus. Service Learning need to be transition into online Service Learning which is also known as Extreme eService Learning. Therefore, it is important to explore the design of this Extreme eService Learning with new possibilities.

The purpose of this study was to investigate students' perception towards engaging factors of Extreme e-Service Learning design for computer network course. The findings of this study indicated engaging factors that determine student engagement are good class activities, attractive features of the online platform and lastly, safe space to share their feeling in online platform. Indeed, educators need be clear with the intended outcomes from the technology used. Particularly in e-Service Learning, interactive learning with technological interactivity is able to enhance student engagement in every phases of e-Service Learning. One limitation of this study is that it is only focus on very small population course that involved e-Service Learning therefore the results cannot be generalized to other e-Service Learning. However, its findings provide deeper insight of engaging factors that can determine student engagement especially in Extreme e-Service Learning. Future research could further investigate the relationship of each engagement factors individually with any generic skills outcomes from the students.

\section{Acknowledgement}

We would like to acknowledge Universiti Teknologi Malaysia (UTM) for sponsoring our work in UTM Encouragement Research vot number Q.J130000.3853.18J82 and Research Management Centre, Universiti Teknologi Malaysia for managing our grant.

\section{$7 \quad$ References}

[1] L. S. Waldner, M. C. Widener, and S. Y. McGorry, "E-service learning: The evolution of service-learning to engage a growing online student population," Journal of Higher Education Outreach and Engagement, vol. 16, no. 2, pp. 123-150, 2012.

[2] V. B. Marcus, N. A. Atan, S. M. Yusof, and L. Tahir, "A Systematic Review of e-Service Learning in Higher Education," International Journal of Interactive Mobile Technologies, vol. 14, no. 06, p. 11, 2020-04-17 2020. https://doi.org/10.3991/ijim.v14i06.13395

[3] L. Waldner, S. McGorry, and M. Widener, "Extreme e-service learning (XE-SL): E-service learning in the $100 \%$ online course," Journal of Online Learning and Teaching, vol. 6, no. 4, pp. 839-851, 2010.

[4] M. Hu and H. Li, "Student engagement in online learning: A review," in 2017 International Symposium on Educational Technology (ISET), 2017: IEEE, pp. 39-43. https://doi.org/ 10.1109/ISET.2017.17

[5] L. S. Waldner and D. Hunter, "Client-based courses: Variations in service learning," Journal of Public Affairs Education, vol. 14, no. 2, pp. 219-239, 2008. https://doi.org/10.1080/ $\underline{15236803.2008 .12001521}$ 
[6] C. B. Kaye, "The Complete Guide to Service Learning: Proven," Practical Ways to Engage Students in Civic Ressponsibility, Academic Curriculum, \& Social Action (Minneapolis: Free Spirit Publ.), 2010.

[7] D. Bharath, "Using eService-Learning to Practice Technical Writing Skills for Emerging Nonprofit Professionals," The Journal of Nonprofit Education and Leadership, vol. 10, no. 1, 2020. https://doi.org/10.18666/JNEL-2020-V10-I1-9420

[8] M. Salam, D. N. Awang Iskandar, D. H. A. Ibrahim, and M. S. Farooq, "Technology integration in service-learning pedagogy: A holistic framework," Telematics and Informatics, vol. 38, pp. 257-273, 2019, https://doi.org/10.1016/j.tele.2019.02.002

[9] M. Griffin, E. Saitta, M. Bowdon, L. J. Walters, M. A. Bowdon, and R. G. Carpenter, Engaging STEM: Service-Learning, Technology, Science Education and Community Partnerships (Higher Education, Emerging Technologies, and Community Partnerships: Concepts, Models, and Practices). 2011, pp. 51-56. https://doi.org/10.4018/978-1-60960-623-7.ch005

[10] P. C. Godfrey, L. M. Illes, and G. R. Berry, "Creating breadth in business education through service-learning," Academy of Management Learning \& Education, vol. 4, no. 3, pp. 309323, 2005. https://doi.org/10.5465/amle.2005.18122420

[11] J. A. Fredricks, Blumenfeld, P. C., \& Paris, A. H., "School engagement: Potential of the concept, state of the evidence," Review of Educational Research, vol. 74(1), pp. 59-109, 2004, https://doi.org/10.3102/00346543074001059

[12] R. Axelson and A. Flick, "Defining Student Engagement: The Magazine of Higher Learning, 43: 1, 38-43," Recuperado em, 2011. https://doi.org/10.1080/00091383.2011.533096

[13] P. C. Schlechty, Engaging students: The next level of working on the work. John Wiley \& Sons, 2011.

[14] R. Stroud, The Use of Technology to Support Theories of Learner Engagement. 2019, pp. 137-140. https://doi.org/10.1145/3318396.3318399

[15] M. Bond and S. Bedenlier, "Facilitating Student Engagement Through Educational Technology: Towards a Conceptual Framework," Journal of Interactive Media in Education, vol. 2019, no. 1, 2019, https://doi.org/10.5334/jime.528

[16] J. Lave and E. Wenger, Situated learning: Legitimate peripheral participation. Cambridge university press, 1991. https://doi.org/10.1017/CBO9780511815355

[17] J. Herrington, R. Oliver, and T. C. Reeves, "Patterns of engagement in authentic online learning environments," Australasian Journal of Educational Technology, vol. 19, no. 1, 2003. https://doi.org/10.14742/ajet.1701

[18] J. Herrington and R. Oliver, "An instructional design framework for authentic learning environments," Educational technology research and development, vol. 48, no. 3, pp. 23-48, 2000. https://doi.org/10.1007/BF02319856

[19] A. M. Saeger, "Using ClassDojo to promote positive behaviors and decrease negative behaviors in the classroom," 2017.

[20] R. Caruso, G. Bowen, and J. Adams-Dunford, "Student Affairs and Service Learning: Promoting Student Engagement," College Student Affairs Journal, vol. 25, no. 2, pp. 186-198, 2006.

[21] R. K. Yin, Case study research and applications: Design and methods. Sage publications, 2017.

[22] H. Cetin and I. Cetin, "Views of Middle School Students about Class Dojo Education Technology," Acta Didactica Napocensia, vol. 11, pp. 89-96, 2018. https://doi.org/10.24193/ adn.11.3-4.7

[23] J. R. A. Santos, "Cronbach's alpha: A tool for assessing the reliability of scales," Journal of extension, vol. 37, no. 2, pp. 1-5, 1999.

[24] D. George and M. Mallery, "Using SPSS for Windows step by step: a simple guide and reference," 2003. 
[25] U. Reja, K. L. Manfreda, V. Hlebec, and V. Vehovar, "Open-ended vs. close-ended questions in web questionnaires," Developments in applied statistics, vol. 19, no. 1, pp. 159-177, 2003.

[26] D. Kaplan, The Sage handbook of quantitative methodology for the social sciences. sage, 2004. https://doi.org/10.4135/9781412986311

[27] E. M. Almarghani and I. Mijatovic, "Factors affecting student engagement in HEIs - it is all about good teaching," Teaching in Higher Education, vol. 22, no. 8, pp. 940-956, 2017, https://doi.org/10.1080/13562517.2017.1319808

[28] S. S. Jaggars, N. Edgecombe, and G. W. Stacey, "Creating an Effective Online Instructor Presence," Community College Research Center, Columbia University, 2013.

[29] M. Cole, "Using Wiki technology to support student engagement: Lessons from the trenches," Computers \& education, vol. 52, no. 1, pp. 141-146, 2009. https://doi.org/ 10.1016/j.compedu.2008.07.003

[30] Z. W. Abas, "Fostering learning in the 21st century through student engagement," International Journal for Educational Media and Technology, vol. 9, no. 1, pp. 3-15, 2015.

[31] N. Bergdahl, U. Fors, P. Hernwall, and O. Knutsson, "The Use of Learning Technologies and Student Engagement in Learning Activities," Nordic Journal of Digital Literacy, vol. 13, pp. 113-130, 06/26 2018, https://doi.org/10.18261/issn.1891-943x-2018-02-04

[32] S. McNicol, C. Lewin, A. Keune, and T. Toikkanen, "Facilitating student reflection through digital technologies in the iTEC project: pedagogically-led change in the classroom," in International Conference on Learning and Collaboration Technologies, 2014: Springer, pp. 297-308. https://doi.org/10.1007/978-3-319-07485-6_30

[33] V. Cohen, Distance learning instruction: A new model of assessment. Association for the Advancement of Computing in Education (AACE), 2002.

[34] L. Darling-Hammond, "Constructing 21st-century teacher education," Journal of teacher education, vol. 57, no. 3, pp. 300-314, 2006. https://doi.org/10.1177/0022487105285962

[35] K. V. Mann, "Reflection's role in learning: increasing engagement and deepening participation," Perspectives on medical education, vol. 5, no. 5, pp. 259-261, 2016. https://doi.org/ 10.1007/s40037-016-0296-y

[36] L. A. Schindler, G. J. Burkholder, O. A. Morad, and C. Marsh, "Computer-based technology and student engagement: a critical review of the literature," International journal of educational technology in higher education, vol. 14, no. 1, p. 25, 2017. https://doi.org/ 10.1186/s41239-017-0063-0

[37] R. C. Chick et al., "Using technology to maintain the education of residents during the COVID-19 pandemic," Journal of Surgical Education, 2020. https://doi.org/10.1016/ j.jsurg.2020.03.018

\section{Authors}

Valerie Bukas Marcus is affiliated with Universiti Teknologi Malaysia, Skudai, Malaysia.

Noor Azean Atan is affiliated with Universiti Teknologi Malaysia, Skudai, Malaysia.

Sanitah Mohd Yusof is affiliated with Universiti Teknologi Malaysia, Skudai, Malaysia.

Umi Mastura is affiliated with Universiti Teknologi Malaysia, Skudai, Malaysia.

Article submitted 2021-01-06. Resubmitted 2021-02-12. Final acceptance 2021-02-14. Final version published as submitted by the authors. 